THE IMPORTANCE OF INNOVATION IN THE PERFORMANCE OF IPO PROCESSES THAT OCCURRED IN BRAZIL DURING THE LAST DECADE

\author{
Murilo Sampaio \\ Universidade Presbiteriana Mackenzie, Brasil
}

\title{
ABSTRACT
}

Innovation is a challenge sought by all economically developed societies. National systems articulate public and private resources so as to shape a more innovative society, capable of ideating and promoting processes, products and services with increasing levels of differentiation before those existing. The search for innovation and the creation of competitive advantages is even greater in the corporate environment, a microeconomic locus where innovation can be measured by efforts and results obtained. Likewise, the number of companies that seek to open themselves to the capital market with views to accumulating resources so as to sustain their strategic growth plans, increases. During the last decade, 245 companies opened their capital in Brazil but only $40 \%$ of these went to São Paulo's Stock Exchange Market (Bovespa) negotiate their shares. Upon making its Initial Public Offering (IPO) the company has to expose to the stock exchange market its true situation in several areas which are ruled by the Securities and Exchange Commission (CVM). They produce extensive documentation in the form of a robust prospect that is made available to any potential investor. The prospect is known at the capital market as the source that portrays the largest amount of information concerning the company that announced their IPO. It is a legal document but, at the same time, one that in highlight contains, all the attributes and differentials that the company expects the market to evaluate. Thus, by means of secondary sources, all ground on the prospects of IPOs that took place, research was conducted to acknowledge the level of innovation each company presented at the time of their IPO and, at the same time, to measure the performance of the value of stocks that the respective IPO obtained. Subsequently a set of structured qualitative interviews posing to evaluate the results of the 
quantitative research, was conducted. The quantitative analysis of data collected did not reveal significance between the innovation variable and the performance stocks obtained at the time of market launch. This same conclusion was ratified during the interviews conducted with the economic agents that operated most of the IPOs which occurred in Brazil. Therefore, despite the relevance of the theme innovation for the qualitative development of an economy (and, in special, for one of the largest economies in the world), results indicate the absence of correlation between innovation and IPO performance. They further offer possible approaches that can extend the study concerning the theme (including other variables, considered of greater relevance and which influence IPO performance), rendering further precision to interpretations and conclusions presented herein.

Key words: Innovation. Processes. IPO. Capital market

\section{A IMPORTÂNCIA DA INOVAÇÃO NO DESEMPENHO DOS PROCESSOS DE ABERTURA DE CAPITAL (IPO) OCORRIDOS NO BRASIL NA ÚLTIMA DÉCADA}

\section{RESUMO}

A inovação é um desafio buscado por todas as sociedades economicamente desenvolvidas. Sistemas nacionais articulam recursos públicos e privados no sentido de tornar a sociedade mais inovadora, capaz de conceber e difundir processos, produtos e serviços com graus crescentes de diferenciação em relação aos existentes. A busca pela inovação e a criação de vantagem competitiva tornam-se ainda maiores no ambiente empresarial, locus microeconômico onde a inovação pode ser aferida pelos esforços e resultados alcançados. Da mesma forma, é crescente o número de empresas que busca abrir-se para o mercado de capitais com o objetivo de acumular recursos a fim de suportar seus planos estratégicos de crescimento. Na última década, 245 empresas abriram seu capital no Brasil, mas apenas $40 \%$ delas foram para a Bolsa de Valores de São Paulo (Bovespa) negociar suas ações. Ao fazer seu IPO 
(Initial Public Offering), a empresa tem de expor ao mercado de capitais sua real situação em diversas áreas regulamentadas pela Comissão de Valores Mobiliários (CVM). Ela produz uma extensa documentação, na forma de um robusto prospecto, que é disponibilizada para todo potencial investidor. O prospecto é conhecido no mercado de capitais como a fonte maior de informações sobre a empresa que faz seu IPO. É uma peça jurídica, mas, ao mesmo tempo, uma peça em que se encontram, com destaque, todos os atributos e diferenciais que a empresa intenciona ver avaliados pelo mercado. Assim, por meio de fontes secundárias, todas fundamentadas nos prospectos dos IPOs realizados, fIO empreendida uma pesquisa para reconhecer o grau de inovação que cada empresa possuía na época de seu IPO e, ao mesmo tempo, para medir o desempenho do valor das ações que o respectivo IPO obteve. Em seguida, fIO realizado um conjunto de entrevistas qualitativas estruturadas com o objetivo de avaliar os resultados da pesquisa quantitativa. A análise quantitativa dos dados coletados não revelou significância entre a variável inovação e o desempenho que as ações obtiveram ao serem lançadas na bolsa. Essa mesma conclusão fIO ratificada nas entrevistas realizadas com os agentes econômicos que operaram a maior parte dos IPOs realizados no Brasil. Assim, a despeito da importância do tema inovação para o desenvolvimento qualitativo de uma economia (e, em especial, para uma das maiores economias do mundo), os resultados apontam para a inexistência de correlação entre inovação e desempenho do IPO. Eles ainda oferecem possíveis abordagens que podem ampliar o estudo sobre o tema (incluindo outras variáveis, julgadas de maior relevância e que influenciam no desempenho do IPO), trazendo maior precisão às interpretações e conclusões aqui apresentadas.

Palavras-chave: Inovação. Processos. IPO. Mercado de capitais 


\section{INTRODUCTION}

Between January 2000 and December 2010, 245 companies in Brazil opened their capital so as to support the expansion plans of their businesses. From these, 97 companies negotiated stock on the exchange market.

The accumulation of capital, originated from the company's opening of capital, is one of the ways to render feasible the production on larger scales, access to broader markets and the development of research at the cutting edge of knowledge and technological domains (Pagano et al., 1998; Brau \& Fawcett, 2006).

From a macroeconomic point of view, it is important to analyse the how the growth of companies that open their capital is progressing. The incorporation of technological innovation in the dynamics of the economy, by means of capital investments, has been essential for the attaining of new development levels since the industrial revolution (Freeman \& Soete, 2008).

Innovation as a source promoting Sustainable Competitive Advantage (SCA) is an increasingly present variable in the building of corporate strategy and, likewise, a status strategic driver so as to impart on growth an innovative bias.

Innovation became a permanent challenge to companies that seek growth (Oslo, 1997). Innovation as a theme is found within companies whether as a top priority with investments (when one may state that the company is innovative) or with low or no priority, thus not being considered as such.

The company researched was that installed in Brazil, which utilizes the national capital market to adjust its capital structure to its strategy. It is a large sized company for Brazilian standards and with the declared intention of sound corporate governance practices. Finally, it is a company that understands that its growth must be coupled to an associative strategy in the definition of its capital structure.

The focus of the research concentrated in two distinct and independent planes: the first, directed to identify the level the company had when it opened its capital. The second plane, directed to the comprehension of the capital 
opening process, verified performance and how the innovation variable influenced the same.

This approach, if adopted at the time the company opens its capital, suggests that, should it be acknowledged as being innovative by means of given indicators, it ought to be higher priced than another similar company that does not present such an attribute. However, empirically, there is no proof that this occurs in Brazil.

The research conducted focused on the moment a company that operates in Brazil - till then of closed capital and thus, without an independent way of pricing its value - opens itself to the market and how the variable innovation influences such a process.

In Brazil, there is a set of institutions that operate directly or indirectly in function of innovation. Part of this set is made up of a series of governmental institutions where planning and discourse praise innovation. "Brazil needs a shock of innovation, in all spheres and dimensions, in the economy and in society. To mobilize Brazil towards innovation is fundamental to accelerate and sustain growth", declared Glauco Arbix, upon taking office as President at Finep Studies and Projects Financing in January 2011.

In the private segment, companies equally demonstrate interest and claim to prioritize innovation. This is almost or effectively unanimous. The question however that remains and finds difficulty to be answered relates to the following contradiction: if innovation is considered so important and even essential to everyone, it seems fit to understand the reasons why efforts are not supported and transformed into results at a scale that is compatible with the size of the Brazilian economy. Whilst Brazil in 2008 only invested 1,09\% of the GNP in activities directed towards innovation (IBGE, 2010), major countries of the European Community and the United States invested two or three times this percentage of their respective GNP's.

If the main sources of financing for the growth of the country's large companies are directly associated with BNDES - the National Economic and Social Development Bank and the capital market, maybe it makes sense to direct special attention to the question of innovation when a large company resorts to these sources of financing. 
Fingerl (2004), the former director of BNDES (from 2006 to 2010), likewise acknowledges the relevance of innovation for the qualified growth of a society's economy. He emphasizes the issue of intangible resources to generate innovation but does not refrain from indicating the operational difficulties that the Bank itself has to overcome to include matters related to innovation when granting credit or when taking on positions at given companies.

No academic research was identified concerning the relation between innovation and the opening of capital on the Brazilian market process. The eventual merit of this study (and its possible use) is, at first, to draw the attention of the investing market to this conceptual gap when investment analysis are conducted, and secondly, within a more ample context, investigate the reasons that drive national companies not to prioritize innovation in their activities, particularly innovation at its initial stage.

\section{THEORETICAL REFERENCE}

Two major constructs had to be implemented to allow the research to be conducted: the first relates to the innovative company and how innovation might be perceived by the capital market; the second seeks to evaluate the performance of the capital opening process.

\subsection{INNOVATIVE COMPANY}

The word innovation takes on several definitions however all comprise the notion that something new is incorporated by the organization, not necessarily an absolute novelty. "Innovation is the use of new knowledge to offer a new product or service that the customer wants. It is invention plus sales" (Freeman \& Soete, 2008). Innovation can also be defined as the adoption of ideas that are new to the organizations that adopt them (Rogers, 1983). Along the same line, innovation is defined as the adoption of an idea or behaviour, whether a system, a policy, a program, an equipment, a process, a product or a service that is new to the organization that adopts it (Damanpour, 1992).

It is important to emphasize that this line of thought concerning innovation is also in line with the institutional perspectives, both international 
(Oslo, 1997) and national (Pintec, 2008), which characterize innovation as changes that involve a significant level of novelty for the company.

It is in the economic arena that innovation displays the largest of its effects driving the society that promotes it. Whether it is a traditional approach whose main stream develops as of a rationalist logic punctuated by balance and growth (Penrose, 1959), or a Schumpeterian vision of innovation as a paradigmatic leap fuelling economic cycles or furthermore, as per the evolutionary vision, whereby small or large innovations are incorporated by a permanent organizational-cultural change (Dosi, 1994, 2002; Nelson \& Winter,1982, 2002; Nelson, 1995). Whatever the nature of the economic approach employed, innovation plays a role in the essence of the development of societies that complete their cycle, from ideation to promotion.

If on one hand, the most relevant acknowledgement for having brought the relevance of innovation to the economy's context was up to Schumpeter, on the other, in his works there is no reference concerning the way organizations structure themselves in search of innovation (Godin, 2008).

In this paper, emphasis was placed on the study of the structuring of innovation and how to recognize it in corporate culture and day-to-day practices (Utterback \& Afuah, 1998; Gopalakrishnan, 2000; Damanpour \& Gopalakrishnan, 2001). The focus is to try to understand the structural elements that make a company be thought of as being more innovative than another, and, subsequently, how the Brazilian capital market perceives such companies.

An innovative company must bring together a series of elements so that the market may evaluate it as such. Innovation such as making better use of resources, generating sustainable competitive advantage, and innovation as a strategic decision to position it in a differentiated manner are examples of such a standpoint. Irrespective of the mode, type or phase, innovation may incorporate itself to the company's day to day as a value, shaping a new culture.

Innovation as an event of economic repercussion, whether radical or incremental, is studied with views to attaining comprehension of the dynamics and of economic cycles and its effects on society. On the other hand, innovation as a phenomenon that structures itself so that it may be implemented is studied in the realm of organizational theories. 
From the macroeconomic arena to a specific and localized environment, the focus is the company (the microeconomic locus), in which innovations are structured and promoted. Innovation is understood as the reply to organizational queries, capable of transforming tangible and intangible resources into competitive advantage. The element of analysis becomes the company and its capacity to explore new ideas, develop innovations and exploit them in the various possible fronts.

Tangible (TR) and intangible (IR) resources according to Barney (1991), Helfat and Peteraf (2003), can establish, as of their improved use, a grounding source for the structuring of strategy. This strategic treatment in dealing with resources, gave rise to what is known as RBV (Resource Based View). Wernerfelt (1984) devoted in-depth effort to this approach and states that the possibility of creating new products is limited to the availability of sound use of available resources. RBV centres on the idea that the nature of corporate resources (as a source of heterogeneity/differentiation) and the way they are managed might lead to the ideation of sustainable competitive advantage (SCA).

Along this same line, Peteraf and Bergen (2003) emphasize the importance of optimizing the use of available resources so as to create SCA, at the same time that a performance cycle is envisioned for them. The objective is to relate intangible resources (IR) and tangible resources (TR) to possible sources generating competitive advantage and innovation.

The organization's strategy is perceived as a managerial element that is capable of gathering resources and positioning them so as to obtain and sustain competitive advantage in relation to competitors. Porter (1985, 1992) establishes the central elements (from cost to technology) so that the strategic positioning of a company may be understood and compared in terms of advantage and differentiation. Innovation in the Porterian universe is clearly associated with the technological transformations companies engage in.

Ettlie et al. (1984) propose a model whereby the way a strategy is structured can more easily lead companies to introduce incremental or radical innovations. Augier and Teece (2008) suggest that strategy is in permanent evolution and emphasize the role of leadership in the process and introduce the 
concept of dynamic "capability" as possible paths to, by means of innovations, explain differentiated performances between companies.

Leadership is understood as an element capable of polarizing the whole organization or even the entire interconnected network with views to launching a new product or developing a new process. The importance of leadership is also consistently proven by theoretical references. Damanpour and Schneider (2006) study the effect of the environment on the phases of innovation, emphasizing the role of corporate upper leadership that conducts the connection function (and that of the required harmonization) between the various stakeholders of the organization.

Ailin and Lindgren (2008) emphasize the importance of leadership at the different stages of innovation but, mostly, in the acculturation that leadership is capable of conducting so that innovation may be something that mingles with the company's own essence.

Damanpour et al. (2009) study the role of leadership at public organizations, pinpointing the fact that the level of innovation (technological or organizational) is directly proportional to the commitment of the upper management. They indicate that the cost of implementing innovations is less relevant than the commitment of leaders.

A last element worthy of note, which does not have a constitutive character with the previous three but in its more ample sense upon what might arise as new and impact society, brings the notion of performance in as much as making these elements effectively introduce an operational paradigm to another level in terms of results, is concerned. These three elements, resources (tangible and intangible), strategy and leadership, are understood as being a source generating competitive advantage given the launch and promotion of innovations: how can one measure the organization's performance? How to measure if such elements modify reality and place the organization on another level? Many are the sources that emphasize the role of innovation in the differentiated performance of companies.

As far as the capital market's perception of performance is concerned, Chaney and Devinney (1991), develop a research that, based on the study of events methodology, relates the impact of the launch of new products to the 
performance of the value of the company's stock. Klomp and Leeuwen (2001), using secondary data bases and mathematical models, relate the initial and final stages of innovations to the respective economic indicators with views to evidencing the effect of innovations on the performance of companies. Cainelli et al. (2004), using secondary data bases, prove that innovative service companies (evaluated as such given the amount expended in R\&D activities) presented a superior performance to that whose investments in innovation were smaller.

Thus, in Figure 1, the above mentioned basic elements which comprise an organization are listed: tangible and intangible resources, leadership and strategy. These three elements shall determine, in their operational environment, performance and its eventual impact on society and its perception of value on the market.

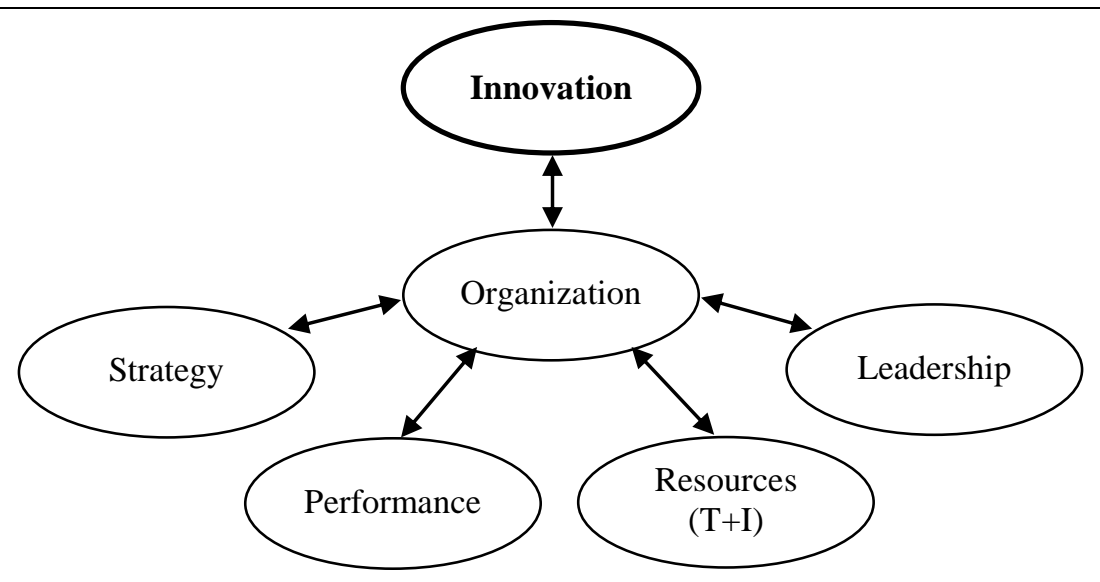

Figure 1: Innovation in the organizational dimension

Source: Author

\subsection{AS TO THE INNOVATION INDICATORS}

Research concerning innovation demands evidence of effort, expenditures, investments and profits that companies employ and reap along the entire process. Almost always, they face difficulties for results to be fully validated mostly due to:

- the selection of indicators that might testify the level of corporate innovation in in general and in particular concerning given phases of the innovation process; 
- the way the process is considered. The equipment acquired to expand the productive capacity is innovation and so are the agreements celebrated with the R\&D organization. They are certainly of different natures, however, for the corporate world (and its pragmatic terminology) both might be considered as innovations;

- the precision of investigations, which can be conducted by means of personal interviews and structured questionnaires at organized companies and with a history in terms of innovation. However, they can be conducted, at the same time, with less severity and at companies that deal with the same activities but in a manner that is specific to their processes.

Figure 2 proposes to the researcher the challenge of identifying which should be the most adequate indicators (in their different phases) to qualify a company's level of innovation.

Inspired by the model proposed by Brown and Svenson (1998), the diagram focuses on innovation as the end of a process which begins when resources are applied to R\&D (inputs) activities up till the end of this preoperational phase when projects and or patents (outputs) are generated. From this figure, relatively simple and easy to prove indicators can be extracted.

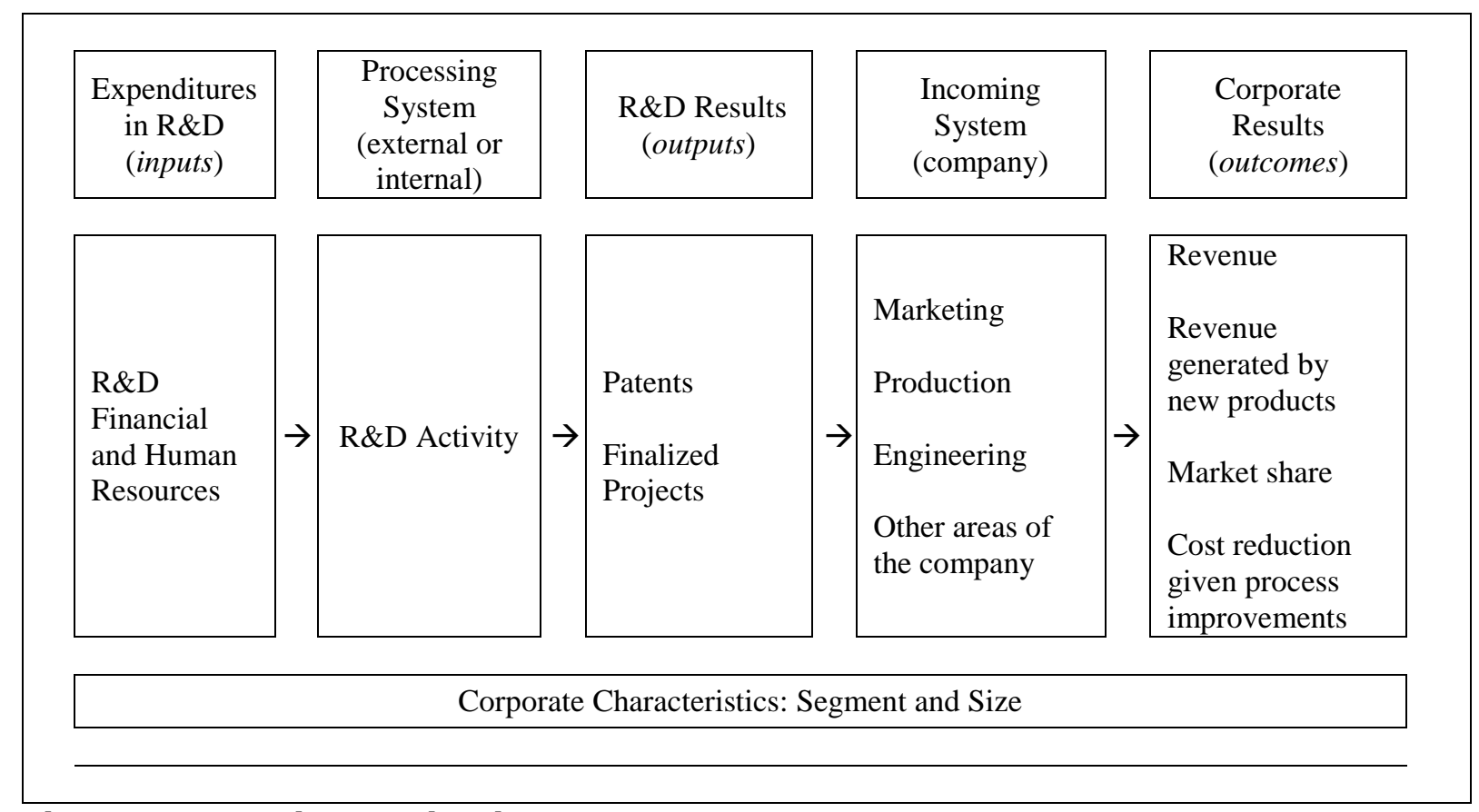

Figure 2: From innovation inputs to outcomes

Source: Brown and Svenson (1998) 


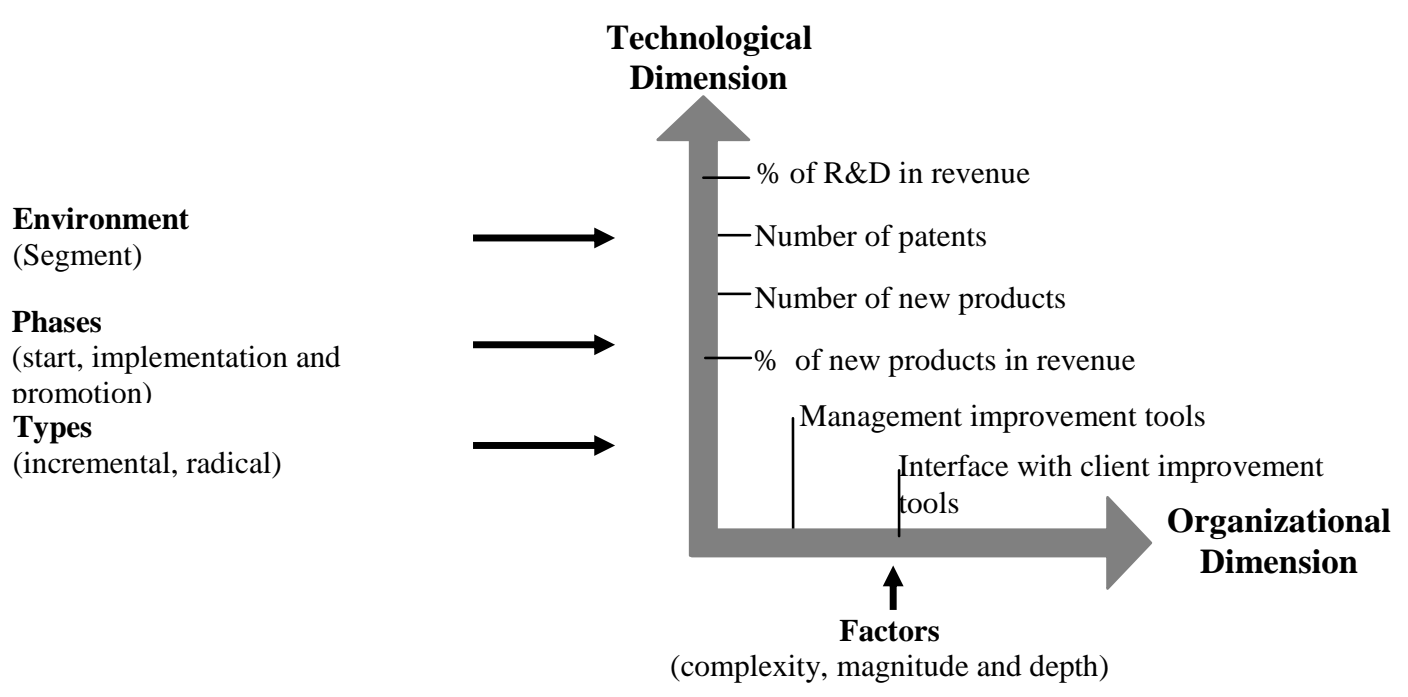

Figure 3: Innovation indicators in the technological and organizational

Source: author dimension

If one conjugates Brown and Svenson's processual approach with the two innovation dimensions in the corporate realm (technology and organizational) one extracts the indicators pictured in Figure 3. All innovative activities - both in the technological ( $R \& D$, obtaining of patents, launch of new products and their importance in revenues) and organizational (tools to improve corporate management and its interface with clients) dimensions - were researched during the data collection phase with views to evaluating the level of innovation at the time of corporate launch on the capital market.

\subsection{OPENING OF CAPITAL}

The theory which offers approaches for the comprehension of growth of the company, proposed by Penrose (1959), whereby given internal and external variables are investigated (primarily with emphasis on resources) highlights, amongst other factors that lead to growth, the relevance of capital for production in larger scales. 
An initial public offering (IPO) as a capitalization alternative, is an important event in the evolution of companies that seek to adjust their capital structure in view of their strategy, plans, challenges and circumstances (Perobelli \& Famá, 2002).

An IPO is conducted by means of the sale of equity to investors. Going to the stock exchange market enables the company access to financial resources in addition to granting greater institutional visibility to the organization itself (Certo et al., 2009). Fingerl's (2004) vision however, is that large and closed companies lose competitiveness.

The growth of the company bears a positive relation with the increase in productivity, with greater market share and consequently, with the company's own value. Mazzola and Marchisio (2002) emphasize these aspects as being the primary motivation for companies to go to the stock exchange market, despite acknowledging the barriers which will have to be overcome.

The motivation to launch shares on the public market, however, is not the same from one company to another. Pagano et al. (1998), after extensive research concerning the real motivation of companies, concluded that the most frequent is the need to rebalance their capital structure, exchanging debt for new shareholders and not the obtaining of resources for future investments, as is the case of many.

In any event, growth (or plans to expand) bears a fundamental role which is often evidenced in the decision of companies to launch into stock exchange at mature markets or emerging economies.

Maksimovic and Pichler (2001), upon discussing about the most adequate moment to call for (and under what circumstances) third party capital for the financing of new industrial products, conclude that three factors have an important role in the process. These are: the market's perception concerning the feasibility of the product (and of the company itself), the probability of a superior technology appearing, and, lastly, the volume of capital required for research and development of similar products by new entrants.

The decision to go to market further has a strategic component once that the need to disclose additional information can compromise the impact, often needed, at the launch of a new product. 


\subsection{THE IMPORTANCE OF PROSPECTS WHEN OPENING CAPITAL}

CVM Ruling $n^{0}$. 400/2003, which covers asset value public offerings, revokes instructions CVM n013/1980 and CVM nº 88/1988. With complementary to legislation enforcement, it poses to regulate and discipline all relevant chapters which must be observed and complied with in the event of issuing bonds thus comprising the initial public offerings of companies that open their capital.

It clarifies the purpose in as much as ensuring and protecting investing public interest is concerned, by means of demands that ensure equal treatment and information to the market in general.

It further deals with issues related to public offerings, deadlines to be complied with, how announcements are to be made and how information to be distributed ought to be disseminated.

In this specific sense, articles 38, 39, 40, 41 and 42 detail the structuring of the document known on the market as a prospect, still poorly known beyond the day to day meanders of those who operate on the capital market.

Jointly prepared by the company and the leading distribution institution, the prospect must contain "(...) complete, precise, true, current, clear, objective and necessary information, in friendly language, so as to ensure that investors may carefully form their investment decision." (CVM)

It is a document that must address several purposes. It is a promotional item, in as much as it must emphasize the qualities and attributes of the issuing company so as to catch the eye of capital markets but it is also, essentially, a legal document that must inform all of the risk factors which are inherent to the company and its business (Cintra, 2006).

All information concerning the terms of the offering, of value, as to the offer, its real estate, economic and financial situation, its warranties, its plans for the destination of resources and several relevant questions must expand its content. So that all mandatory information is provided and, at the same time, all information perceived as relevant and attractive from the investor's point of 
view is supplied, prospects end up becoming large sized compendiums, some reaching almost one thousand pages.

\subsection{PERFORMANCE DEFINITION OF THE CAPITAL OPENING PROCESS AND SELECTION OF AVAILABLE VARIABLES WITH VIEWS TO MEASUREMENT}

The concept of performance must be understood as of a system whose frontiers are clearly and previously defined, subject to traceable observation and with precise measures of the researched variables.

When the performance of capital opening processes started to be evaluated, two major categories as to an IPO's performance evaluation were identified: short term performance and long term performance (Certo et al., 2009).

As to the short term category, performance is evaluated in a manner that relates to the launch price of shares and their pricing during the first auction or at, almost always, intervals of less than one year. Factors that can impact market evaluation during the first auction, as well as the respective comparison with the price evaluated as of its accounting value (Fama \& French, 1992) might, in the short term, contribute with the evaluation of an IPO's performance. However, one of the most important variables, if not the most important, is under pricing measured at the first action in view of the range of stipulated values for share launch. If a share remains within its range, the IPO's performance measure can be evaluated in function of the closing price obtained in the first auction as that which rests closer to the lower or upper limit of the range.

Summarizing the theoretical reference, the configuration below lists the major conceptual blocks that comprise hues and details in each of its stages. The research undertaken is situated in this sequence and sought to embrace the various factors raised in the theoretical reference so far herein covered. 


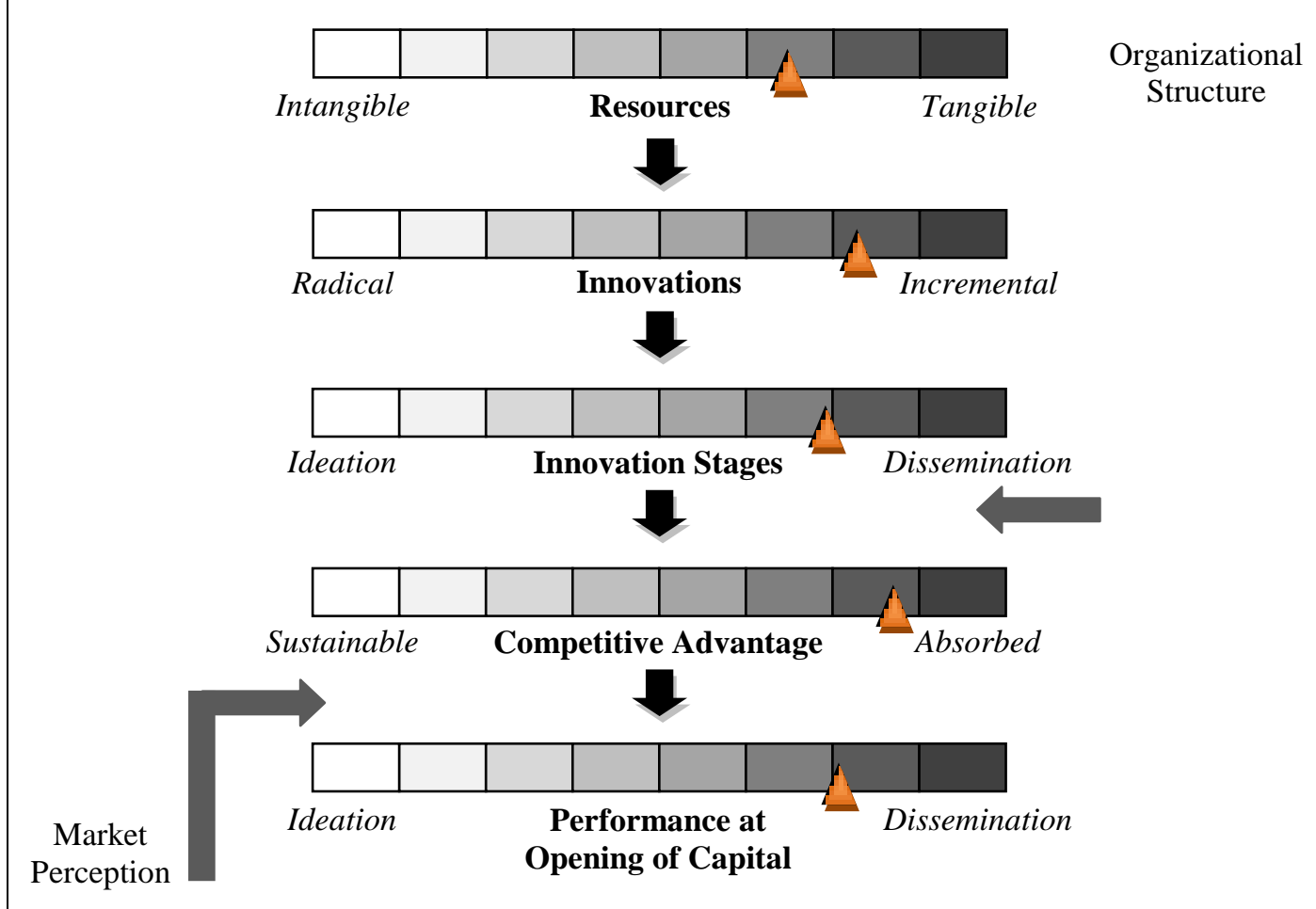

Figure 4: Innovation, its structure and capital markets perception (or synthesis of the theoretical reference)

Source: author

\section{HYPOTHESIS TO BE TESTED}

The greater the level of innovation of a company, the better is its performance during its opening of capital process.

\section{METHODOLOGICAL PROCEDURES AND RESEARCH STAGES}

\subsection{COLLECTION OF DATA}

The object of this research is the identification and characterization of the relationship innovation has with the performance of the company's opening of capital process and thus, test the hypothesis formulated. So that this relationship might be known and analysed, a survey was conducted on the preliminary and final prospects of each of the 97 companies that opened their capital and started to negotiate their shares on the stock exchange market, so as to: 
a) collect data relevant to the range of values desired for the shares and of the value reached at the IPO. Thus, the IPO's performance (PD variable) was calculated;

b) verify the number of times that the word innovation was mentioned in the text so that subsequently, the origin of the mentioned innovation might be identified. Thus, innovation was classified as organizational (variable OI) or technological (variable TI).

After compiling the variables $\mathrm{PD}, \mathrm{OI}$ and $\mathrm{TI}$, the possible correlations between them were studied. Subsequently, the qualitative phase of the research was initiated whereby ten structured interviews were conducted with companies that had opened capital and with capital market agents so as to discuss the results gathered as of the information contained in the prospects.

\subsection{DATA ANALYSIS}

The objective of the analysis was to verify a possible correlation between the number of citations of the word innovation stated in the IPO prospects (utilized as implementation of the innovation construct) and the performance of the opening obtained by the company. Three approaches were utilized for this verification:

1. linear correlation analysis (utilizing the quantitative value that is the absolute number of citations of the word innovation);

2. association analysis utilizing categorized values;

3. analysis comparing the average opening performance between the groups without citation or with some mention of the word innovation.

\subsubsection{Linear correlation analysis}

At this stage of the study, interest resided in evaluating the linear correlations between the numbers of citations of the word innovation (technological, organizational and overall) and the opening performance value. 
To verify these correlations between scales, Spearman's coefficient was employed. The results of the correlation coefficients are presented in Table 1. Values above 0,8 are considered strong correlations. Those under 0,5 are considered poor correlations.

Observing the results of correlations one notices that, in all situations there is a poor correlation between the number of citations and the performance value, thus not confirming the hypothesis formulated.

Table 1: Spearman's correlation coefficient
\begin{tabular}{|l|c|}
\hline $\begin{array}{l}\text { Performance } \\
\text { at Opening }\end{array}$ \\
\hline $\begin{array}{l}\text { Organizational } \\
\text { Innovations }\end{array}$ & $-0,072$ \\
\hline $\begin{array}{l}\text { Technological } \\
\text { Innovations }\end{array}$ & 0,219 \\
\hline $\begin{array}{l}\text { Innovations } \\
\text { (total) }\end{array}$ & $\mathbf{0 , 1 3 9}$ \\
Source: author
\end{tabular}

\subsubsection{Association analysis}

For this analysis, the number of citations was classified into categories. Given the large number of companies with no citation, classifications in the following categories were conducted: no citation; one; more than one.

For the IPO performance value the following classification was utilized: groups with performance value up to 1 and above 1 .

To compare categories of quantities of citations in relation to categories of performance value, the Chi-Squared test was employed. For all tests, a level of significance of $5 \%$ was considered. Thus, differences between groups when $\mathrm{p}$ value was smaller than 0,05 ( $p$-value $<0,05$ ) were considered.

From the results presented in Table 2, one might observe that there was no association between the number of citations and the IPO's performance value in any of the situations $(p>0,05)$, once again not confirming the hypothesis formulated. 
Table 2: Association between innovation and performance at opening

\begin{tabular}{|c|c|c|c|c|c|c|}
\hline & & \multicolumn{4}{|c|}{ Performance at Opening } & \multirow{3}{*}{$p$-value } \\
\hline & & \multicolumn{2}{|c|}{ Up to 1} & \multicolumn{2}{|c|}{ Above 1} & \\
\hline & & $N$ & $\%$ & $n$ & $\%$ & \\
\hline \multirow{2}{*}{$\begin{array}{l}\text { Organizational } \\
\text { innovations }\end{array}$} & None & 32 & $68,1 \%$ & 33 & $66,0 \%$ & \multirow[b]{2}{*}{0,827} \\
\hline & $\begin{array}{l}\text { More than } \\
\text { once }\end{array}$ & 15 & $31,9 \%$ & 17 & $34,0 \%$ & \\
\hline \multirow{2}{*}{$\begin{array}{l}\text { Technological } \\
\text { innovations }\end{array}$} & None & 36 & $76,6 \%$ & 31 & $62,0 \%$ & \multirow[b]{2}{*}{0,121} \\
\hline & \begin{tabular}{|l|}
$\begin{array}{l}\text { More than } \\
\text { once }\end{array}$ \\
\end{tabular} & 11 & $23,4 \%$ & 19 & $38,0 \%$ & \\
\hline \multirow{2}{*}{$\begin{array}{l}\text { Innovations } \\
\text { (total) }\end{array}$} & None & 22 & $46,8 \%$ & 17 & $34,0 \%$ & \multirow[b]{2}{*}{0,199} \\
\hline & $\begin{array}{l}\text { More than } \\
\text { once }\end{array}$ & 25 & $53,2 \%$ & 33 & $66,0 \%$ & \\
\hline
\end{tabular}

Source: author

\subsubsection{Comparison of the average performance value between groups without citation or with some citation of the word innovation}

In the comparisons that follow, the concern was to evaluate if the performance value was, on average, greater in the group where there was at least one citation of the word innovation. For these comparisons, the t-Student was utilized considering a level of significance of $5 \%$. Thus it was considered that there was a difference between groups when $p<0,05$.

From the results that follow (both for organizational innovation, technological and total), one can notice that there was no difference in the IPO's average performance between the groups (no citation, once or more). One can only observe that there was a trend $(0,05<p<0,10)$ whereby companies that stated once or more the technological innovation citation, presented, on average, a higher performance value $(1,11)$ than those that did not mention the word $(1,04)$. This analysis, much like the previous ones, also did not confirm the hypothesis formulated. 
Table 3: Performance at opening by group of organizational citations

\begin{tabular}{|l|c|c|}
\hline \multirow{2}{*}{} & \multicolumn{2}{|c|}{$\begin{array}{c}\text { Organizational } \\
\text { innovations } \\
\text { (citations) }\end{array}$} \\
\cline { 2 - 3 } & None & $\begin{array}{c}\text { Once or } \\
\text { more }\end{array}$ \\
\hline $\mathrm{N}$ & 66 & 32 \\
\hline Average & 1,07 & 1,04 \\
\hline $\begin{array}{l}\text { Standard } \\
\text { Deviance }\end{array}$ & 0,19 & 0,15 \\
\hline Minimum & 0,62 & 0,69 \\
\hline Maximum & 1,48 & 1,38 \\
\hline \multicolumn{3}{|c|}{ p-value $=0,415$} \\
\hline
\end{tabular}

Source: author

Table 4: Performance at opening by group of technological citations

\begin{tabular}{|l|c|c|}
\hline \multirow{2}{*}{} & \multicolumn{2}{|c|}{$\begin{array}{c}\text { Technological } \\
\text { innovations } \\
\text { (citations) }\end{array}$} \\
\cline { 2 - 3 } & None & $\begin{array}{c}\text { Once or } \\
\text { more }\end{array}$ \\
\hline $\mathrm{N}$ & 68 & 30 \\
\hline Average & 1,04 & 1,11 \\
\hline $\begin{array}{l}\text { Standard } \\
\text { Deviance }\end{array}$ & 0,17 & 0,19 \\
\hline Minimum & 0,69 & 0,62 \\
\hline Maximum & 1,40 & 1,48 \\
\hline \multicolumn{3}{|c|}{ p-value $=0,062$} \\
Source: author
\end{tabular}

Table 5: Performance at opening by group of total innovation citations

\begin{tabular}{|l|c|c|}
\hline \multirow{2}{*}{} & \multicolumn{2}{|c|}{$\begin{array}{c}\text { Total innovations } \\
\text { (citations) }\end{array}$} \\
\cline { 2 - 3 } & None & $\begin{array}{c}\text { Once or } \\
\text { more }\end{array}$ \\
\hline $\mathrm{N}$ & 40 & 58 \\
\hline Average & 1,05 & 1,08 \\
\hline $\begin{array}{l}\text { Standard } \\
\text { Deviance }\end{array}$ & 0,18 & 0,17 \\
\hline Minimum & 0,69 & 0,62 \\
\hline Maximum & 1,40 & 1,48 \\
\hline \multicolumn{3}{|c|}{$\begin{array}{c}\text { p-value }=0,430 \\
\text { Source: author }\end{array}$} \\
\hline
\end{tabular}


As the research's final stage, structured interviews were conducted with the major agents of the capital market that operate and coordinate more than two thirds of all IPOs conducted in Brazil (Itaú Bank, Bank of Brazil, Bradesco Bank, Santander Bank and JP Morgan Bank). In addition to economic agents, structured interviews were likewise conducted with companies that opened their capital.

At all interviews, several variables considered relevant for the performance of the IPO were presented. All indicated as essential the variables "context at the time of the IPO", "share's intended value" and "resource destination plan". Virtually at the same level, truly close to these variables, was that of "corporate governance".

The "innovation" variable, placed amongst the others, did not have its importance acknowledged, confirming the results of the quantitative analysis. That is, the market still does not in practice consider innovation as something of relevance to the IPO.

Furthering the specific matter of innovation, economic agents did not present consistent knowledge concerning the theme and even less so as to organizational innovation. As from a brief conceptual explanation concerning technological innovation of products and services and organizational innovation, corner stoning both international (OCDE/Oslo) and national (IBGE/Pintec) institutional bases, interviews proceeded smoothly.

\section{FINAL CONSIDERATIONS}

Conducting research that associates a broad and of multiple approaches theme such as innovation with a quantitative result such as the verification of performance of a company's opening of capital (IPO) may call for care and additional procedures to those mentioned in the present article.

Even though there are obvious fronts to be researched so that the theme may be exhausted (the role that other variables provided in the opening of corporate capital, the conceptualization of the IPO's performance with more extended horizons, the implementation of the innovation construct as of primary research, amongst other aspects), one may affirm that the theme innovation 
does not play a role of relevance in performance companies obtain when they open themselves to the capital market in Brazil.

There seems to be a theoretical consensus as to the importance of innovation for companies and for society as a whole but such relevance is not perceived when evaluations focus on the time the company launches itself on the market. Such an event, that frontiers the transition from a closed company to an open, transparent and publically negotiated one, might serve to disclose the plans the organization presents in terms of innovation and the eventual contribution to be made for the qualitative improvement of the segment it operates in. Given the research conducted, one cannot as yet state that this takes place in the country.

\section{BIBLIOGRAPHY}

Ailin, M. \& Lindgren, P. (2008). Conceptualizing strategic innovation leadership for competitive survival and excellence. Journal of Knowledge Globalization, 1(2).

Arbix, G. (2011, 28 de fevereiro). Discurso de posse na Financiadora de Estudos e Projetos. Finep, Rio de Janeiro.

Augier, M.; Teece, D. J. (2008). Strategy as evolution with design: the foundations of dynamic capabilities and the role of managers in the economic system. Organization Studies, 29(7\&8), 118-1208.

Barney, J. (1991). Firm resources and sustained competitive advantage. Journal of Management, 17(1).

Brau, J. C.\& Fawcett, S. E. (2006). Initial public offerings: an analysis of theory and practice. Journal of Finance, 61(1), 399-436.

Brown, M. G. \& Svenson, R. A. (1988). Measuring R\&D productivity. Research Technology Management, 31(número), 11-13.

Cainelli, G. et al. (2004). The impact of innovation on economic performance in services. Service Industries Journal, 24(1).

Certo, S. T. et al. (2009). IPO research in management and entrepreneurship: moving the agenda forward. Journal of Management, 35(6), 1340-1378.

Chaney, P. K. \& Devinney, T. M. (1992). New product innovation and stock price performance. Journal of Business Finance \& Accounting, 19

Cintra, A.F.A. O prospecto de oferta pública". (2006). Revista Capital Aberto, seção IPO em foco, n. 38.

Comissão de Valores Mobiliários. CVM. Recuperado em 15 de fevereiro, 2011, de http://www.cvm.gov.br. 
Damanpour, F. (1992). Organizational size and innovation. Organization Studies, 13(3).

Damanpour, F. \& Gopalakrishnan, S. (2001). The dynamics of the adoption of product and process innovations in organizations. Journal of Management Studies, 38(1).

Damanpour, F. \& Schneider, M. (2006). Phases of the adoption of innovation in organizations: effects of environment, organization and top managers. British Journal of Management, 17(3).

Damanpour, F. et al. (2009). Combinative effects of innovation types and organizational performance: a longitudinal study of service organizations. Journal of Management Studies, 46(4).

Ettlie, J. E. et al. (1984). Organization strategy and structural differences for radical versus incremental innovation. Management Science, 30(6), 682695.

Fama, E. F. \& French, K. R. (1992). The cross-section of expected stock returns. Journal of Finance, 47, 427-465.

Fingerl, E. R. (2004). Considerando os intangíveis: Brasil e BNDES. Dissertação de Mestrado, Programa de Pós-graduação de Engenharia, Universidade Federal do Rio de Janeiro: RJ, Rio de Janeiro, Brasil.

Freeman, C. \& Soete, L. (2008). A economia da inovação industrial. Campinas, SP: Unicamp.

Godin, B. (2008). In the shadow of Schumpeter: W. Rupert Maclaurin and the study of technological innovation. Minerva: a Review of Science, Learning \& Policy, 46(3), 343-360.

Gopalakrishnan, S. (2000). Unraveling the links between dimensions of innovation and organizational performance. Journal of High Technology Management Research, 11(1).

Helfat, C. E. \& Peteraf, M. A. (2003). The dynamic resource-based view: capability lifecycles. Strategic Management Journal, 24(10), 997-1010.

Klomp, L. \& Leeuwen, V. (2001). Linking innovation and firm performance: a new approach. International Journal of the Economics of Business.

Maksimovic,V. \& Pichler, P. (2001). Technological innovation and initial public offerings. The Review of Financial Studies, 14(2), 459-494.

Mazzola, P. \& Marchisio, G. (2002). The role of gIOng public in family businesses. Long-lasting growth: a study of Italian IPOs. Family Business Review, 16(2).

Nelson, R. R. (1995). Recent evolutionary theorizing about economic change. Journal of Economic Literature, 33(1), 48-90.

Nelson, R. R. \& Winter, S. G. (1982). An evolutionary theory of economic change. Cambridge: Harvard University Press.

Nelson, R. R. \& S. Winter, G. (2002). Evolutionary theorizing in economics. The Journal of Economic Perspectives, 16(2), 23-46. 
Oslo, M. (1997). Manual de Oslo.

Pagano, M. et al. (1998). Why do companies go public? An empirical analysis. Journal of Finance, 53(1), 27-64.

Penrose, E. (Ed.) (1959-2006). A teoria do crescimento da firma. Campinas: Unicamp.

Perobelli, F. F. C. \& Famá, R. (2002). Determinantes da estrutura de capital: aplicação a empresas de capital aberto brasileiras. Revista de Administração (RAUSP), 37(3).

Peteraf, M. A. \& Bergen, M. E. (2003). Scanning dynamic competitive landscapes: a market-based and resource-based framework. Strategic Management Journal, 24(10), 1027-1041.

Porter, M. E. (1985). Competitive advantage. New York: Free Press.

Porter, M. E. (1992). Vantagem competitiva: criando e sustentando um desempenho superior. Rio de Janeiro: Campus

Rogers, E. M. (1983). Diffusion of innovation. New York: Free Press.

Schumpeter, J. A. (1912). The theory of economic development. New York: Oxford University Press.

Utterback, J. M.;\& Afuah, A. N. (1998). The dynamic 'diamond': a technological innovation perspective. Economics of Innovation \& New Technology, 6(2/3), 183-1999.

Wernerfelt, B. (1984). A resource-based view of the firm. Strategic Management Journal, 5(2), 171-180. 